\title{
Vulnerability of copepod eggs in salinity and temperature gradients of the Marmara and Black Seas
}

\author{
Leonid Svetlichny ${ }^{1, *}$, Elena Hubareva ${ }^{1}$, Genuario Belmonte ${ }^{2}$, Melek Isinibilir ${ }^{3}$, \\ Funda Ustun ${ }^{4}$, I. Noyan Yilmaz ${ }^{5}$, Benin Toklu-Alıclı ${ }^{6}$ \\ ${ }^{1}$ Institute of Biology of the Southern Seas, Sevastopol 99011, Crimea, Ukraine \\ ${ }^{2}$ Marine Biology Station, University of the Salento, 73100 Lecce, Italy \\ ${ }^{3}$ Faculty of Fisheries, Istanbul University, 34130 Laleli, Istanbul, Turkey \\ ${ }^{4}$ Faculty of Fisheries, Sinop University, Sinop 57000, Turkey \\ ${ }^{5}$ Institute of Marine Sciences and Management, Istanbul University, 34470 Vefa, Istanbul, Turkey \\ ${ }^{6}$ Department of Biology, Faculty of Science, Istanbul University, 4118 Vezneciler, Istanbul, Turkey
}

\begin{abstract}
Mass density, sinking speed and hatching success of eggs in Calanus euxinus, Acartia clausi and A. tonsa have been examined in response to salinity and temperature of the Marmara and Black Seas. Eggs of $C$. euxinus from the Marmara and Black Sea populations (mean mass density of 1.036 to $1.040 \mathrm{~g} \mathrm{~cm}^{-3}$ ) laid in brackish (18 to $22 \mathrm{psu}$ ) upper layers of the Marmara Sea could sink to high-saline ( $38.5 \mathrm{psu})$ deep layers during embryonic development. Gradual salinity increase from 22 to $38.5 \mathrm{psu}$ in laboratory experiments reduced egg hatching success in $C$. euxinus from the Marmara Sea from $97 \pm 4$ to $47 \pm 11 \%$ (means \pm SD) while all eggs of the Black Sea $C$. euxinus did not hatch. Mean mass density of eggs in A. tonsa and A. clausi amounted to 1.062 and $1.044 \mathrm{~g} \mathrm{~cm}^{-3}$, respectively. Eggs of $A$. tonsa with higher mass density and longer development time than those of A. clausi could descend to high salinity strata in the Marmara Sea, or to a cold intermediate layer in the Black Sea. On the contrary, sinking depth of eggs of A. clausi should not exceed $30 \mathrm{~m}$ both in the Black and Marmara Seas, as this increases predator pressure. Hatching success in A. tonsa eggs laid at $18 \mathrm{psu}$ decreased from $77.7 \pm 18.5 \%$ at $20^{\circ} \mathrm{C}$ to $46.7 \pm 21.5 \%$ at $7^{\circ} \mathrm{C}$, and reduced to $10.2 \pm$ $4.7 \%$ at $7^{\circ} \mathrm{C}$ and $39 \mathrm{psu}$. Egg hatching success in A. clausi from the Black Sea did not depend upon temperature, whilst it decreased dramatically from 80 to $90 \%$ to 3.3 to $10 \%$ after salinity increase from 18 to $38 \mathrm{psu}$.
\end{abstract}

KEY WORDS: Calanus euxinus · Acartia clausi · Acartia tonsa - Egg mass density · Hatching success · Salinity and temperature tolerance $\cdot$ Black Sea $\cdot$ Marmara Sea

\section{INTRODUCTION}

Environmental parameters such as salinity and temperature have been considered as the main factors affecting temporal and spatial distribution patterns of copepods (Conover 1956, Miller \& Marcus 1994, Mauchline 1998).

The Marmara and Black Seas are characterized by different salinity and temperature regimes. Upper lay- ers of the Marmara Sea ( 0 to $20 \mathrm{~m}$ ) are formed by the Black Sea water with a salinity of 18 to 22 psu and temperature ranging from $20-24^{\circ} \mathrm{C}$ in summer to $8-9^{\circ} \mathrm{C}$ in winter, while the Mediterranean Sea water with constant salinity of $38.5 \mathrm{psu}$ and temperature of $\sim 15^{\circ} \mathrm{C}$ lies deeper than 30 to $40 \mathrm{~m}$ (Kocatas et al. 1993). The salinity gradient in the 20 to $30 \mathrm{~m}$ thick layer of the Marmara Sea reaches 20 psu. On the contrary, in the Black Sea, salinity changes slightly from 18 psu near the sur- 
face to $22 \mathrm{psu}$ at depths $>150 \mathrm{~m}$. However, due to a permanent cold intermediate layer $\left(6\right.$ to $\left.8^{\circ} \mathrm{C}\right)$, a pronounced temperature gradient (up to $16^{\circ} \mathrm{C}$ ) occurs at depths of 20 to $30 \mathrm{~m}$ during the warm season, i.e. summer (Vinogradov et al. 1992).

Copepods Calanus euxinus, Acartia clausi and A. tonsa are the key species in the Black Sea. C. euxinus is a cold-water perennial species inhabiting principally deep regions of the Black Sea (Vinogradov et al. 1992). The eurythermic copepod A. clausi occurs throughout the year in shallow coastal waters of the Black Sea (Kovalev et al. 1998). A. tonsa, a nearshore species (Paffenhöfer \& Stearns 1988, Tester \& Turner 1991) that was introduced in the Black Sea with ship ballast waters in the 1970's (Gubanova 1997), develops in May (when water temperature reaches $15^{\circ} \mathrm{C}$ ) and can be found in the innermost area of the bays until December (Gubanova 2000).

The Black Sea copepods penetrate into the Marmara Sea through the Bosphorus Strait. According to Svetlichny et al. (2010), an euryhaline sub-population of Calanus euxinus inhabiting both upper brackish and deep, high-saline layers is formed in the north-western Marmara Sea from stenohaline specimens recruiting from the Black Sea. Due to acceleration of the development of this species at the high temperature and salinity of the Marmara Sea, small-sized pre-adults and adults without large lipid reserves, which are typical for the Black Sea C. euxinus, occur in this area (Isinibilir et al. (2009).

Hubareva et al. (2008) showed that the Black Sea Acartia clausi transferred into the Marmara Sea did not survive after gradual salinity increase from 18 to 30 psu. These authors reported about the dramatic decrease in the abundance of A. clausi in the Marmara Sea, in comparison to the Black Sea, due to mass mortality (up to $66 \%$ ) of copepodites and adults in the salinity gradient layer. On the contrary, adult A. tonsa were alive after salinity increase from 18 to 39 psu. However, the abundance of this species also decreased sharply in the direction from the Black Sea toward the Marmara Sea. A similar phenomenon was reported by Cervetto et al. (1999) for the northern Mediterranean, near Marseille (France). In their study, A. tonsa from the brackish waters of the Berre Lagoon (10 to $12 \mathrm{psu}$ ) were tolerant to high salinity ( 35 to $38 \mathrm{psu}$ ) for several days but were absent from the neighboring Gulf of Fos (35 to $40 \mathrm{psu}$ ). In the Mediteranean area, A. tonsa were found also in the lagoons of the northern and southern Adriatic Sea (Farabegoli et al. 1989, Sei \& Ferrari 2008) and Sardinian lagoon (Zagami \& Guglielmo 1990). Isolated individuals of $A$. tonsa were found in the bays of the southern coast of Turkey (Uysal et al. 2002). According to Brylinski (1981), A. tonsa occur in European waters of estuarine type characterized by a lower salinity and a higher temperature than the adjacent off-shore waters.

Hubareva et al. (2008) suggest that this phenomenon may be connected with a low salinity tolerance of the juvenile stages of Acartia tonsa. In fact, a number of studies have shown that young stages are more sensitive and, consequently, have narrower survival limits than adult copepods (Nagaraj 1988, Villante et al. 1993). Tester \& Turner (1991) showed that survival of $A$. tonsa nauplii decreased rapidly at salinities $>25$ psu and temperatures $<20^{\circ} \mathrm{C}$. In the experiments of Holste \& Peck (2006), the eggs did not hatch within $168 \mathrm{~h}$ when incubated at temperatures $<10.5^{\circ} \mathrm{C}$. CastroLongoria (2003) found no hatching success at either 10 or $5^{\circ} \mathrm{C}$ after $6 \mathrm{~d}$ of incubation. Only a few nauplii of $A$. tonsa from 309 eggs laid were observed at $6^{\circ} \mathrm{C}$ during the experiment of Pedersen (2005). According to Hansen et al. (2010), in non-acclimatized $A$. tonsa, hatching success sharply reduced down to $34.4 \%$ when temperature decreased to $9^{\circ} \mathrm{C}$ and was high ( $\left.90 \%\right)$ when females were reared at low temperature. This may explain why warm-water A. tonsa can develop all year round in the Adriatic lagoons where the temperature decreases down to $7^{\circ} \mathrm{C}$ in winter (G. Belmonte pers. comm.).

In free-spawning copepod species like Calanus and Acartia, mass density of eggs is higher than water density (Salzen 1956, Miller \& Marcus 1994, Tang et al. 1998, Knutsen et al. 2001); during embryonic development, eggs may descend to a depth of a few tens of meters (Landry 1978, Uye 1980b, Sazhina 1987, Roman et al. 1993, Miller \& Marcus 1994), aggregating sometimes lower than the layers of inhabitance of females (Williams et al. 1987). Sinking of copepod eggs may decrease predatory pressure and cannibalism on eggs and young nauplii (Daan et al. 1988, Ohman \& Hirche 2001, Bonnet et al. 2004). However, sinking of eggs in environmental gradients may affect their survival because salinity and temperature can have a direct effect on the hatching success of copepod eggs (Uye \& Fleminger 1976, Drillet et al. 2008, Ohs et al. 2009, Hansen et al. 2010).

Estimation of sinking speed of copepod eggs based on mass density has rarely been reported in the literature (Salzen 1956, Marcus \& Fuller 1986, Miller \& Marcus 1994, Knutsen et al. 2001). Similar studies on eggs of the Black Sea copepods have not been conducted and little is known about their salinity and temperature tolerance during the embryonic period.

The aim of the present study was to estimate the sinking speed of Calanus euxinus, Acartia clausi and A. tonsa eggs throughout the salinity gradient of the Marmara Sea and the temperature gradient of the Black Sea, and to examine potential effects of sharp increase in salinity and decrease in temperature on survival of eggs of these species. 


\section{MATERIALS AND METHODS}

Copepod sampling. Adult Calanus euxinus were collected during daytime using a Nansen net (opening diameter: $50 \mathrm{~cm}$, mesh size: $200 \mu \mathrm{m}$ ) by vertical hauls between the bottom and the surface in December 2006 at a permanent station near the Prince Islands in the Marmara Sea (MP; 40 51.43' N, 28 57.67' E, depth of $\sim 200 \mathrm{~m}$ ) and in February-March and June 2007 in the inlet part of the Bosphorus $\left(\mathrm{MB}_{i} 40^{\circ} 59.32^{\prime} \mathrm{N}\right.$, $28^{\circ} 59.33^{\prime} \mathrm{E}$, depth of $\sim 50 \mathrm{~m}$ ). This was repeated in February 2007 in the Black Sea near Sevastopol (BSS; $44^{\circ} 39.04^{\prime} \mathrm{N}, 33^{\circ} 24.24^{\prime} \mathrm{E}$, depth of $\left.\sim 80 \mathrm{~m}\right)$. Acartia clausi were collected by horizontal (10 min) net tows in the 0-20 m layer in June 2007 at MP, and in July 2008 at BSS. Acartia tonsa were collected in July 2008 also by horizontal net tows in Sevastopol Bay $\left(44^{\circ} 37.28^{\prime} \mathrm{N}\right.$, $\left.33^{\circ} 30.46^{\prime} \mathrm{E}\right)$.

After sampling, adult females of Calanus euxinus, Acartia clausi and A. tonsa were sorted using a widemouth pipette and incubated in $1.0 \mathrm{l}$ aquaria (not more than 20 individuals for Calanus or 50 for Acartia, respectively) filled with $0.45 \mu \mathrm{m}$-filtered natural seawater (18-22 and 17-18 psu for the specimens from MP and BSS, respectively) with an excess of food (dinoflagellate Prorocentrum minimum for $C$. euxinus and diatom Thalassiosira weissflogii for A. clausi and A. tonsa). For the experiments with C. euxinus collected at MP, we selected only small-sized (prosome length: 1.9 to $2.2 \mathrm{~mm}$ ) females (see Isinibilir et al. 2009, Svetlichny et al. 2010). For the experiments with $C$. euxinus collected from the upper layers in the Bosphorus area (near Istanbul), we selected large females (prosome length: 2.5 to $2.8 \mathrm{~mm}$ ). The females of $C$. euxinus sampled at BSS were used without size selection. We did not conduct similar selection for A. clausi because we found no regional differences in body length for this species.

The aquaria with Calanus euxinus were kept at $8^{\circ} \mathrm{C}$ in the dark, and the aquaria with Acartia were maintained in a constant temperature room at $20 \pm 1{ }^{\circ} \mathrm{C}$ under a natural light:dark cycle and continuously aerated by blowing air on the top.

Experimental set-up. The day after sampling 20 to 30 females of Calanus euxinus or 30 to 50 females of Acartia clausi and A. tonsa, they were transferred in 3 to 5 crystallizing dishes containing $200 \mathrm{ml}$ of $0.45 \mu \mathrm{m}$ filtered seawater and kept for $1 \mathrm{~h}$ at $20^{\circ} \mathrm{C}$. After that, all eggs laid by copepod females were collected.

Two types of experiments were conducted to investigate the effect of salinity on Calanus euxinus egg hatching success. To simulate salinity changes during descending of $C$. euxinus eggs laid in the upper layers across salinity gradient of the MP, at least 80 freshly spawned eggs were placed into 5 replicate crystalliz- ing dishes containing $10 \mathrm{ml}$ of filtered seawater at $20 \pm$ $1^{\circ} \mathrm{C}$ and underwent gradual salinity increases from $17-18$ to $38-39$ psu (in BSS females) and from 22 to 38-39 psu (MP females) at a rate of $1.5 \mathrm{psu} \mathrm{h}^{-1}$, and, additionally, from 22 to $38-39$ psu at a rate of $0.7-5.7 \mathrm{psu} \mathrm{h}^{-1}$ (to study the effect of rate of salinity changes on hatching success of the MP specimens) by substituting the Black Sea water for high-saline water. We obtained seawater with high salinity by mixing water from surface (22 psu) and deep (38-39 psu) layers of the Marmara Sea or adding artificial sea salt to the Black Sea water (17-18 psu). Water salinity was measured by a HACH conductivity meter 'SensIon 5' using Practical Salinity Scale. The duration of the experiment and rate of salinity change were determined based on the expected time of transport of eggs across the salinity gradient of the Marmara Sea $(10-15 \mathrm{~m})$ and taking into account that in the Black Sea at 8 to $18^{\circ} \mathrm{C}$, egg sinking speed in $C$. euxinus amounted to $0.9-1.8 \mathrm{~m} \mathrm{~h}^{-1}$ and embryonic development time took no less than $1 \mathrm{~d}$ (Sazhina 1987). During each experiment, 10 to 20 eggs (from the total number of $\sim 80$ eggs) were kept at $20^{\circ} \mathrm{C}$ in seawater of initial salinity of 17-18 and 22 psu (for the experiments with BSS and MP specimens, respectively); the rest of the eggs, after a gradual salinity increase, were maintained at terminal (39 psu) and several (3-5 psu) intermediate salinities. We monitored the development of eggs up to the hatch or decomposition, for $3 \mathrm{~d}$.

To simulate salinity changes experienced by Acartia clausi and A. tonsa eggs during their descending from the upper brackish layer to the deep high-saline layer of the Marmara Sea, about 30 newly spawned eggs (removed 25 to $30 \mathrm{~min}$ after spawning) were put into 5 replicate crystallizing dishes containing $3 \mathrm{ml}$ of filtered seawater. Crystallizing dishes were kept at $20^{\circ} \mathrm{C}$ during $\sim 20 \mathrm{~h}$ without the covers in order to increase the salinity from 17-18 psu (for the BSS A. clausi and A. tonsa) or 22 psu (for the MP A. clausi) to 39 psu by evaporating the water. The salinity was measured using a hand refractometer RHS10ATC. The duration of salinity changing $(20 \mathrm{~h})$ corresponds to embryonic development time of these species at $20^{\circ} \mathrm{C}$ (Pedersen 2005, Uye 1980a). During this time, sinking eggs of $A$. tonsa can cover the distance of $\sim 15 \mathrm{~m}$ (Miller \& Marcus 1994) conforming to the thickness of the halocline layer in the Marmara Sea. At $7^{\circ} \mathrm{C}$ the duration of salinity changing by evaporation was $48 \mathrm{~h}$.

To study the influence of low temperature on hatching success in Acartia clausi and A. tonsa, the eggs of these species placed into crystallizing dishes were gradually cooled from a temperature of $20^{\circ} \mathrm{C}$ down to $7^{\circ} \mathrm{C}$ during $10 \mathrm{~h}$. To obtain cumulative effect of temperature and salinity on hatching success in A. clausi 
and $A$. tonsa, the eggs were exposed to simultaneous decrease in temperature and increase in salinity by water evaporation. Hatching success was determined by counting the number of nauplii and unhatched eggs during an incubation period of $2 \mathrm{~d}$ at $20^{\circ} \mathrm{C}$ and $6 \mathrm{~d}$ at $7^{\circ} \mathrm{C}$, which corresponded with the time needed to obtain the maximum hatching success in the eggs of non-acclimatized females of $A$. tonsa at close temperatures (Hansen et al. 2010). At termination of the experiment at $7^{\circ} \mathrm{C}$, the non-hatched eggs were transferred to $20^{\circ} \mathrm{C}$ and observed during $48 \mathrm{~h}$ to test their viability.

To examine the effect of temperature on nauplii of BSS Acartia tonsa, we counted the number of actively swimming and immobile individuals during $1 \mathrm{~d}$ after their birth from eggs laid at low salinity (18 psu) and temperatures of $6,8,15,23$ and $24^{\circ} \mathrm{C}$. Eight to 10 freshly born active nauplii were transferred to $2 \mathrm{ml}$ crystallizing dishes placed into a thermostatically controlled chamber and frequency and distance of horizontal jumps from initial and final position were registered under the dissecting microscope at a magnification of $16 \times$ using a digital camera, DCM 500. The parameters of locomotion of $1 \mathrm{~d}$ old nauplii were expressed as the means obtained from 5 trails of 1 min for each nauplius during $1 \mathrm{~h}$.

Measurements of sinking speed and mass density. Sinking speed and mass density of eggs obtained from Calanus euxinus females collected in MP, MB and BSS were studied at a temperature of 21.1 to $21.9^{\circ} \mathrm{C}$ and salinity of 16.8 to $18.7 \mathrm{psu}$. Mass density of Acartia clausi and $A$. tonsa eggs were examined only in the Black Sea at a temperature of 24.2 to $25.5^{\circ} \mathrm{C}$ and a salinity of 16.5 to 17.2 psu. Newly spawned eggs collected from several females were put in crystallizing dishes of $200 \mathrm{ml}$. Before the sinking speed measurement, the eggs were acclimatized to the conditions of the experiment during 3 to $4 \mathrm{~h}$.

To determine sinking speed of copepod eggs, individual eggs of Calanus euxinus or batch of eggs of Acartia clausi and A. tonsa were transferred, using a pipette, into a $20 \mathrm{~cm}$ long graduated glass tube $(\varnothing$ : $1 \mathrm{~cm}$ ) filled with filtered seawater of given density and temperature. To minimize the effects of water convection, the tube was completely submerged in a cylinder $(\varnothing: 3 \mathrm{~cm})$ with water of constant temperature agitated by a pump. Sinking speed of eggs was monitored using a binocular microscope focused on the central axis of the tube. We have found previously (Stepanov \& Svetlichny 1981) that the walls of a vessel can affect the speed of sinking of copepods if the individual is near the wall (closer than 10 body lengths). Therefore we discarded data when the distance between the eggs and the walls of the vessel was less than 1 to $2 \mathrm{~mm}$.
The eggs of studied species from the Calanus and Acartia genera have a spherical form (Belmonte 1998) and their Reynolds numbers (Re) during their sinking were much less than 0.4 (maximum values of $\mathrm{Re}$ amounted to 0.14 and 0.016 for $C$. euxinus and $A$. tonsa, respectively). Consequently, mass density of copepod eggs $\left(\rho, \mathrm{g} \mathrm{cm}^{-3}\right)$ was determined from sinking speed $\left(V, \mathrm{~cm} \mathrm{~s}^{-1}\right)$ following the Stokes equation (Happel \& Brenner 1965): $\rho=\left(3 \pi d v+\rho_{\mathrm{w}} g V\right) / g V$, where $v$ is the kinematic molecular viscosity $\left(\mathrm{cm}^{2} \mathrm{~s}^{-1}\right), d$ is the egg diameter $(\mathrm{cm}), \rho_{\mathrm{w}}$ is the corresponding density of the seawater $\left(\mathrm{g} \mathrm{cm}^{-3}\right)$, while $g$ is the acceleration due to the gravity, $981 \mathrm{~cm} \mathrm{~s}^{-2}$, and $V$ is the egg volume calculated as $V=\pi d^{3} / 6$. The density of seawater was calculated taking into account the temperature (measured with the accuracy of $0.1^{\circ} \mathrm{C}$ ) and salinity (determined by a Conductivity Probe SensIon 5 having an accuracy of $0.1 \mathrm{psu}$ ) using the Oceanological calculator 2.1 by V. S. Arhipkin. Egg diameters were measured in a subsample of 40 to 80 eggs under a compound microscope at $400 \times$. In $A$. tonsa, the diameters of eggs were measured without taking into account thin and short $(\sim 2 \mu \mathrm{m})$ surface spines.

For statistical analysis of the data, 1-way ANOVA and the Student's $t$-test were used. Average values presented in the text and figures are means \pm SD.

\section{RESULTS}

\section{Diameter, sinking speed and mass density of Calanus euxinus eggs from the Black and Marmara Seas}

For eggs laid by small females (prosome length of 1.9 to $2.2 \mathrm{~mm}$ ) collected in December 2006 at MP (surface temperature and salinity of $12^{\circ} \mathrm{C}$ and $22 \mathrm{psu}$, respectively), and eggs laid by large females (prosome length of 2.6 to $2.7 \mathrm{~mm}$ ) collected in February 2007 at MB (surface temperature and salinity of $8^{\circ} \mathrm{C}$ and $19 \mathrm{psu}$, respectively) and at $\mathrm{BSS}\left(8^{\circ} \mathrm{C}\right.$ and $\left.18 \mathrm{psu}\right)$, the modal intervals of egg diameter amounted to $172-180 \mu \mathrm{m}$ (Fig. 1). Minimum egg diameters of females from the Black and Marmara Seas were also similar $(\sim 168 \mu \mathrm{m})$, while maximum egg diameter in the Black Sea Calanus euxinus $(195 \mu \mathrm{m})$ was higher than that in large females collected at MB $(188 \mu \mathrm{m})$ and small females collected at MP (182 $\mu \mathrm{m})$. Average diameters of eggs laid by $C$. euxinus females collected at MP $(174.8 \pm 2.9 \mu \mathrm{m})$ was significantly $(\mathrm{p}<0.01)$ lower than those of eggs laid by females collected at BSS (179.2 \pm $5.6 \mu \mathrm{m})$.

Mean sinking speed of eggs laid by females captured at MP at a temperature of 21.1 to $21.2^{\circ} \mathrm{C}$ and salinity of $18.7 \mathrm{psu}\left(0.036 \pm 0.01 \mathrm{~cm} \mathrm{~s}^{-1}\right)$ was significantly $(p<0.05)$ lower than that of eggs laid by 

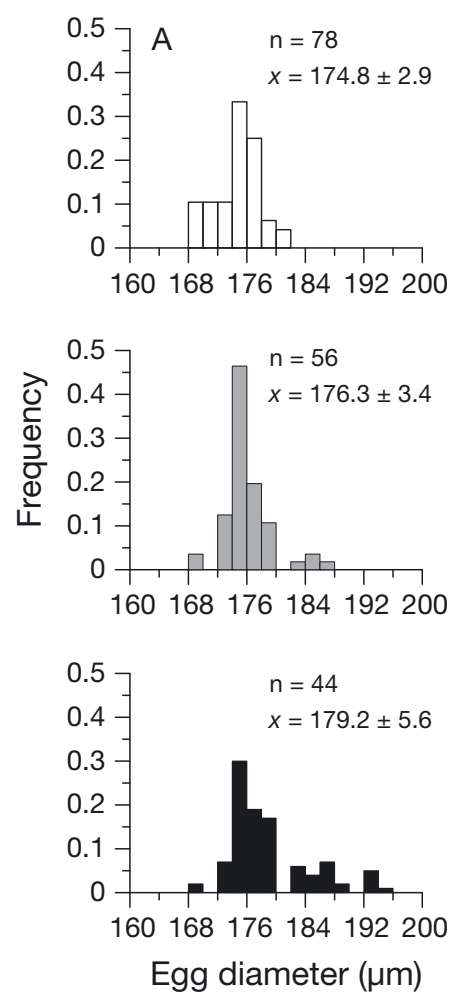
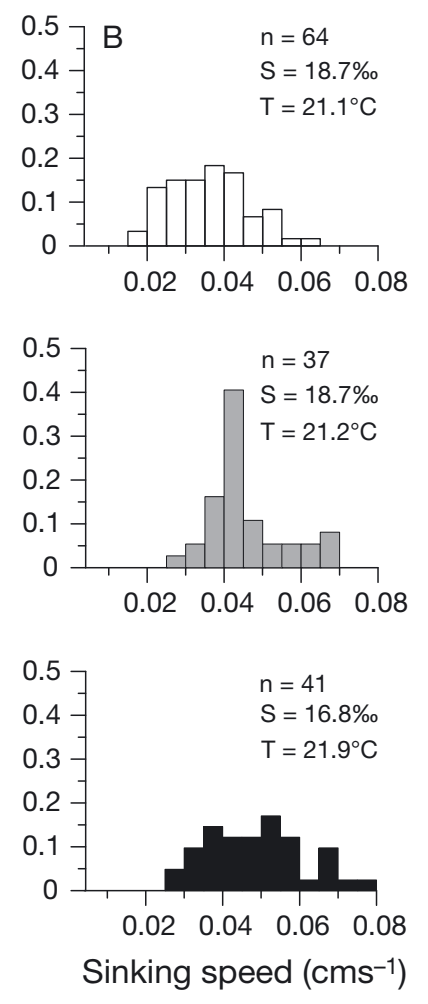
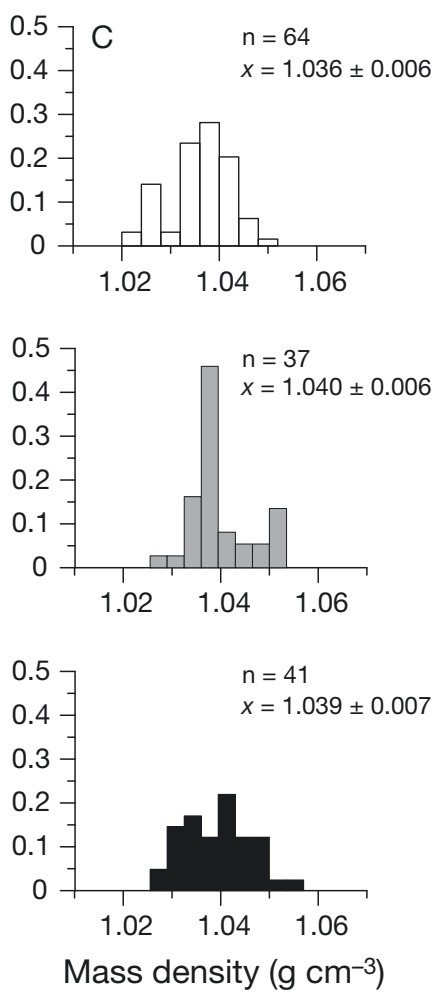

Fig. 1. Calanus euxinus. (A) Diameter, (B) sinking speed and (C) mass density of eggs laid by females collected in the Marmara Sea near the Prince Islands (white bars) and Bosphorus (grey bars), and in the Black Sea near Sevastopol (black bars). Prosome lengths in females collected in the Marmara Sea near the Prince Islands: $1.9-2.3 \mathrm{~mm}$; in other cases: $2.6-2.7 \mathrm{~mm}$. S: salinity, $\mathrm{n}$ : number of eggs, $\mathrm{T}$ : temperature, $x$ : mean $\pm \mathrm{SD}$

females collected at $\mathrm{MB}$ at the same temperature and salinity $\left(0.046 \pm 0.01 \mathrm{~cm} \mathrm{~s}^{-1}\right)$ and at BSS at the temperature of $21.9^{\circ} \mathrm{C}$ and salinity of $16.8 \mathrm{psu}(0.049$ $\pm 0.013 \mathrm{~cm} \mathrm{~s}^{-1}$ ).

The range of mass density of eggs from the Marmara Sea small females (1.024 to $1.050 \mathrm{~g} \mathrm{~cm}^{-3}$ ) was shifted to lower values in comparison with that of eggs from the Black Sea large females (1.027 to $\left.1.055 \mathrm{~g} \mathrm{~cm}^{-3}\right)$. However, mean mass densities did not differ significantly $\left(1.036 \pm 0.006\right.$ and $1.040 \pm 0.006 \mathrm{~g} \mathrm{~cm}^{-3}$, respectively).

\section{Diameter and mass density of eggs in Acartia clausi and $A$. tonsa from the Black Sea}

Diameter of eggs in Acartia clausi and A. tonsa (measured without spines) amounted to 69-78 and $74-83 \mu \mathrm{m}$, respectively (Fig. 2). Mass density of eggs in A. clausi at a salinity of 16.5 to 17.2 psu and temperature of 24.2 to $25.5^{\circ} \mathrm{C}$ varied in limits of 1.036 to $1.055 \mathrm{~g}$ $\mathrm{cm}^{-3}$ with a mean value of $1.044 \pm 0.005 \mathrm{~g} \mathrm{~cm}^{-3}$. In $A$. tonsa, egg mass densities at the same salinity and temperature stayed between 1.048 and $1.075 \mathrm{~g} \mathrm{~cm}^{-3}$ with a mean value of $1.062 \pm 0.007 \mathrm{~g} \mathrm{~cm}^{-3}$.

\section{Effect of salinity on hatching success of eggs laid by Calanus euxinus from the Black and Marmara Seas at low salinity}

During the gradual salinity increase from 17-18.7 to 37-39 psu at a rate of $1.5 \mathrm{psu} \mathrm{h}^{-1}$, the eggs from the Black Sea females died at salinities $>30 \mathrm{psu}$, in contrast to the eggs produced by the Marmara Sea females at the same salinity increase speed (Fig. 3A).

The salinity increase from 21.8 to 29-30 psu did not affect the hatching success $(97 \pm 4 \%)$ of eggs from the Marmara Sea small females, whilst after a further salinity increase up to $39 \mathrm{psu}$ at a rate of $1.5 \mathrm{psu} \mathrm{h}^{-1}$, egg hatching success decreased to $47 \pm 11 \%$. Hatching success of these eggs after a salinity increase to $39 \mathrm{psu}$ strongly $\left(\mathrm{r}^{2}=0.92\right)$ depended on the salinity changing rate (Fig. 3B) ranging from $100 \%$ (at a rate of $0.7 \mathrm{psu}$ $\mathrm{h}^{-1}$ ) to $33 \%\left(\right.$ at $5.7 \mathrm{psu} \mathrm{h}^{-1}$ ).

In the salinity range of 30 to $39 \mathrm{psu}$, the eggs of Calanus euxinus became wrinkled due to loss of water. However, after a long term high salinity exposition (up to $2 \mathrm{~d}$ ), the eggs that survived recovered their regular spherical shape indicating the ability of eggs to absorb seawater. Although at $\sim 20^{\circ} \mathrm{C}$ the development time of Calanus eggs usually amounts to $\sim 1 \mathrm{~d}$, in our experi- 


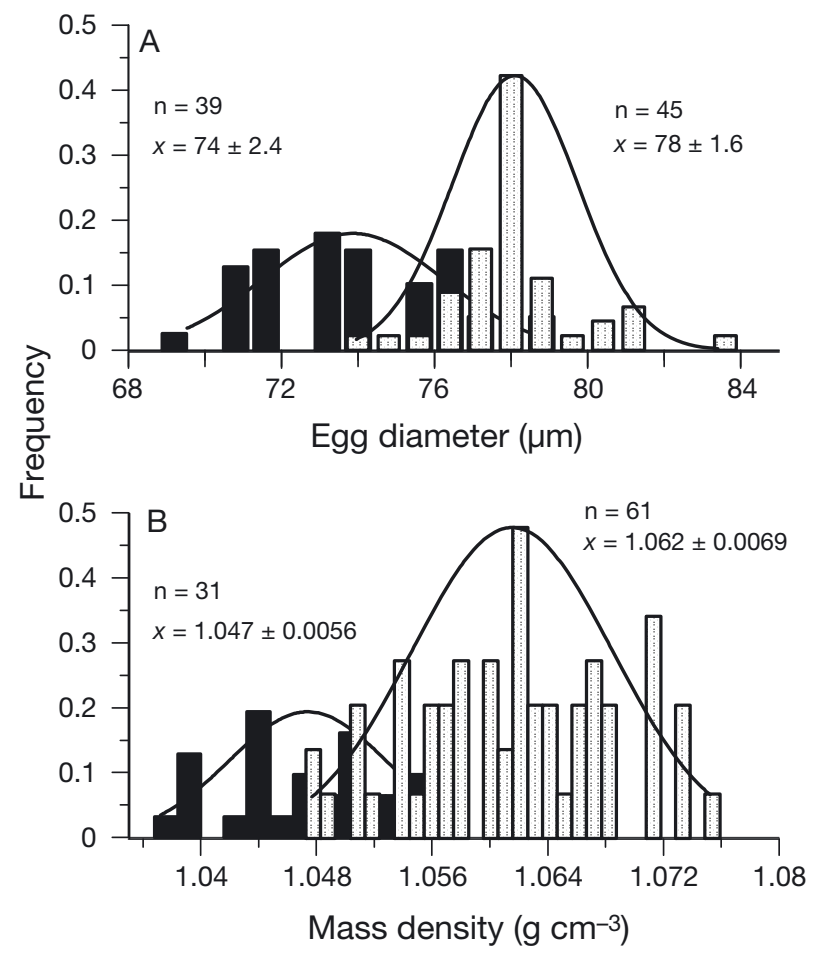

Fig. 2. Acartia clausi and A. tonsa. (A) Diameter and (B) mass density of eggs laid by females of $A$. clausi (black) and A. tonsa (grey) collected in the Black Sea near Sevastopol. See Fig. 1 for definitions

ments at the same temperature, egg development time of $C$. euxinus increased up to $2 \mathrm{~d}$ after high salinity exposition.

\section{Effect of salinity and temperature on hatching success of eggs laid by Acartia clausi from the Marmara and Black Seas and $A$. tonsa from the Black Sea}

At $20^{\circ} \mathrm{C}$ and $22 \mathrm{psu}$, the hatching success of eggs laid by Acartia clausi collected in the upper layers of the Marmara Sea near the Prince Islands $\left(24.6^{\circ} \mathrm{C}\right.$, $22 \mathrm{psu}$ ) amounted to $84.2 \pm 14.9 \%$. At $38.5 \mathrm{psu}$, the hatching success of eggs laid by the same females (Fig. 4) was also high both at $20^{\circ} \mathrm{C}(51.4 \pm 29.5 \%)$ and $7^{\circ} \mathrm{C}(73.6 \pm 10.5 \%)$. In A. clausi collected in the Black Sea at $25.5^{\circ} \mathrm{C}$ and after a salinity increase from 18 to $39 \mathrm{psu}$, the egg hatching success decreased dramatically from $80 \pm 12$ to $7.5 \pm 3.5 \%$ (at $20^{\circ} \mathrm{C}$ ) and from $84 \pm 8$ to $6.7 \pm 2.7$ (at $7^{\circ} \mathrm{C}$ ). In $A$. tonsa collected at $26^{\circ} \mathrm{C}$, the egg hatching success at $20^{\circ} \mathrm{C}$ and $18 \mathrm{psu}$ $(77.7 \pm 18.5 \%)$ was significantly higher $(\mathrm{p}<0.01)$ than that at $7^{\circ} \mathrm{C}$ and 18 psu $(46.7 \pm 21.5 \%)$ and $7^{\circ} \mathrm{C}$ and 39 psu $(10.2 \pm 4.7 \%)$. At termination of the experiment conducted at $7^{\circ} \mathrm{C}$ during $6 \mathrm{~d}$, the remain-

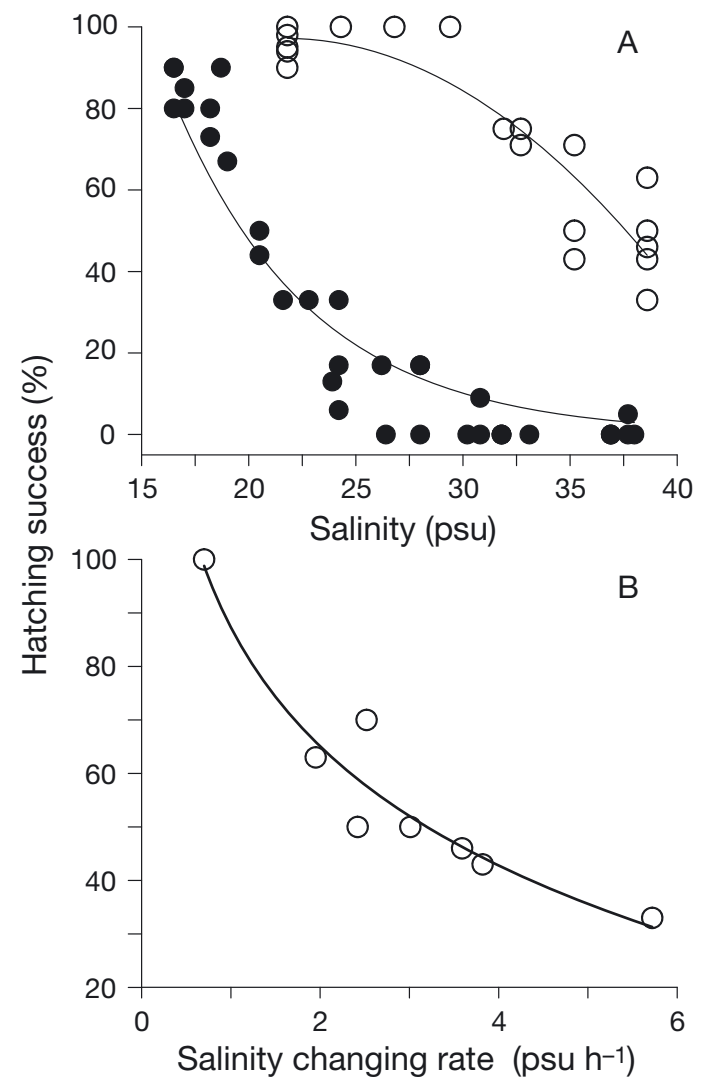

Fig. 3. Calanus euxinus. Effect on hatching success of eggs from (A) Black Sea (๑) and Marmara Sea (O) females in a gradual salinity increase at a rate of $1.5 \mathrm{psu} \mathrm{h}^{-1}$ and (B) Marmara Sea females in a salinity changing rate of $0.7-5.7 \mathrm{psu} \mathrm{h}^{-1}$

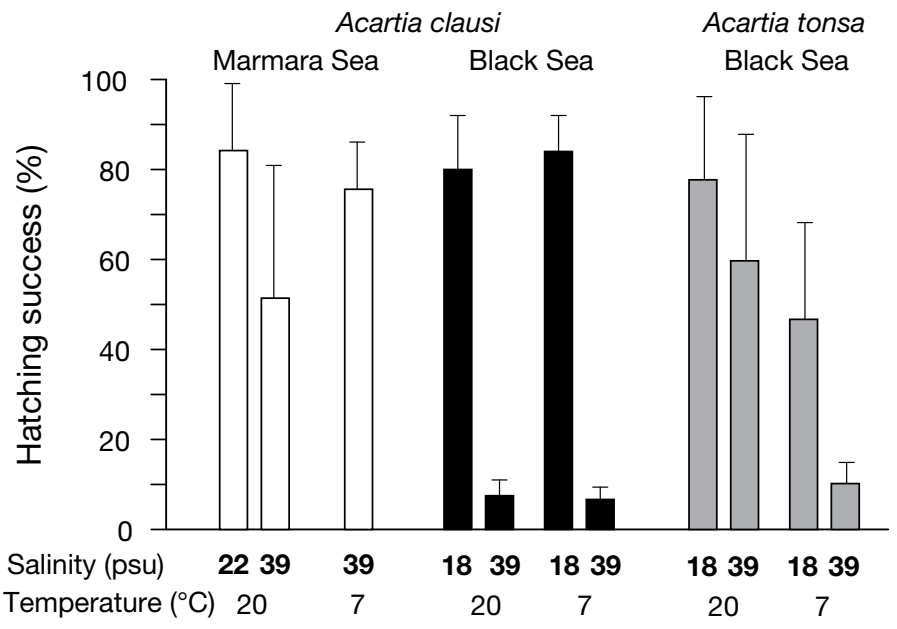

Fig. 4. Acartia clausi and A. tonsa. Hatching success of eggs laid by $A$. clausi from the Marmara and Black Seas and $A$. tonsa from the Black Sea at salinities of 18,22 and 39 psu and temperatures of 7 and $20^{\circ} \mathrm{C}$

ing eggs were transferred to $20^{\circ} \mathrm{C}$ to hatch. After $48 \mathrm{~h}$ at high temperature, all the non-hatched eggs decayed. 


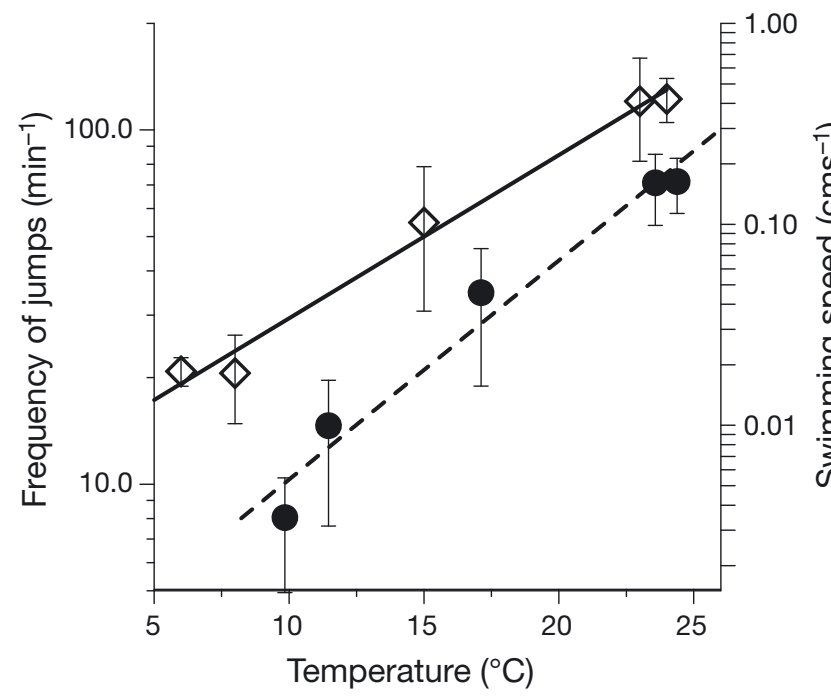

Fig. 5. Acartia tonsa. Effect of temperature on frequency of jumps $(\diamond)$ and swimming speed $(\bullet)$ in newly hatched nauplii

\section{Effect of temperature on moving activity of newly hatched nauplii of Acartia tonsa}

If incubated at 6 to $8^{\circ} \mathrm{C}, 40$ to $60 \%$ of newly hatched nauplii of Acartia tonsa were immobile with weakly moving limbs. Active nauplii performed 20 jumps $\mathrm{min}^{-1}$, which allowed them to move horizontally with mean swimming speed of $0.0035 \pm 0.0020$ and $0.0099 \pm$ $0.0068 \mathrm{~cm} \mathrm{~s}^{-1}$ at temperatures 6 and $8^{\circ} \mathrm{C}$, respectively. In the range of 15 to $24^{\circ} \mathrm{C}$, almost all the nauplii were active. The frequency of jumps and the mean swimming speed of nauplii at $24^{\circ} \mathrm{C}$ reached $122.4 \pm 17.4$ jumps $\mathrm{min}^{-1}$ and $0.16 \pm 0.05 \mathrm{~cm} \mathrm{~s}^{-1}$, respectively (Fig. 5).

\section{DISCUSSION}

\section{Diameter and mass density of copepod eggs}

Diameter and mass density in free spawned eggs of copepods affect their sinking speed and vertical distribution in the sea water column. According to our results, diameters of eggs laid by Calanus euxinus females from the Marmara and Black Seas amounted to 168-182 and 168-195 $\mu \mathrm{m}$, respectively. These values are close to egg diameter of the cogeneric species $C$. helgolandicus from the English Channel reported as 165-180 (Marshall et al. 1953), 150-185 (Guisande \& Harris 1995) and 161-178 $\mu \mathrm{m}$ (Poulet et al. 1995), but significantly higher than egg diameter $(163 \pm 0.4 \mu \mathrm{m})$ in $C$. helgolandicus from the water off the coast of North West Spain (Ceballos et al. 2004).
Hence, genetic differences between the Black Sea Calanus euxinus and mother species C. helgolandicus from the Northern-east Atlantic and Adriatic Sea are exceedingly subtle (Papadopoulos et al. 2005, Unal et al. 2006) that we may consider their populations as geographic variations of one species.

Fleminger \& Hulsemann (1987) reported that the prosome length of Calanus helgolandicus females from the Mediterranean Sea was much lower than that of $C$. euxinus from the Black Sea. Average prosome length in females collected from the Ionian Sea near Taranto during the present study in March 2009 (unpubl. data) amounted to $2.16 \pm 0.14 \mathrm{~mm}$ and average diameter of eggs laid by these females was $162 \pm 11 \mu \mathrm{m}$. However, despite the fact that prosome lengths in females from the Marmara Sea $(2.01 \pm 0.04 \mathrm{~mm})$ were lower than those from the Ionian, the diameters of eggs laid by them $(174.8 \pm 2.9 \mu \mathrm{m})$ were significantly $(\mathrm{p}<0.001)$ higher than those of females from the I onian Sea and close to egg diameters from the Black Sea population $(179.2 \pm 5.6 \mu \mathrm{m})$. This phenomenon and the fact that mean mass density of eggs laid by the Marmara Sea $\left(1.036 \pm 0.006 \mathrm{~g} \mathrm{~cm}^{-3}\right)$ and the Black Sea $(1.040 \pm 0.006$ $\mathrm{g} \mathrm{cm}^{-3}$ ) females did not differ significantly $(\mathrm{p}>0.05)$ are in agreement with our suggestion about the origin of the Marmara Sea C. euxinus from the Black Sea population (Isinibilir et al. 2009).

Gross \& Raymont (1942) reported that the density of Calanus finmarchicus eggs constituted 1.045 to $1.049 \mathrm{~g}$ $\mathrm{cm}^{-3}$. In their study, an egg diameter was equal to $190 \mu \mathrm{m}$, whilst that parameter for C. finmarchicus amounted to $135 \pm 4 \mu \mathrm{m}$ (Salzen 1956). Therefore, Salzen (1956) suggested that the eggs studied by Gross \& Raymont belonged to another species. Nevertheless, egg densities obtained by Gross \& Raymont (1942) slightly exceeded those in C. euxinus.

In the experiments of Salzen (1956) at $22^{\circ} \mathrm{C}$ and a salinity of $35 \mathrm{psu}$, mass density of Calanus finmarchicus eggs was equal to $1.074 \pm 0.002 \mathrm{~g} \mathrm{~cm}^{-3}$. Knutsen et al. (2001) found that for 2 ecological groups of C. finmarchicus living in the Barents Sea at 34.5 to $35 \mathrm{psu}$ and $\sim 0^{\circ} \mathrm{C}$, mean mass density of eggs amounted to 1.0639 and $1.0812 \mathrm{~g} \mathrm{~cm}^{-3}$, respectively, while for $C$. glacialis, that parameter was equal to only $1.0556 \mathrm{~g}$ $\mathrm{cm}^{-3}$. Higher mass density of eggs in these species in comparison with the Black Sea C. euxinus seems to be due to higher salinity of oceanic water.

Miller \& Marcus (1994) reported that salinity strongly affected egg mass density. It was shown that at $20^{\circ} \mathrm{C}$ mass density of Acartia tonsa eggs spawned at 31 and $15 \mathrm{psu}$ amounted to 1.087 and $1.066 \mathrm{~g} \mathrm{~cm}^{-3}$, respectively. In our experiments at 24.2 to $25.5^{\circ} \mathrm{C}$, we found a close mean mass density of $1.062 \pm 0.007 \mathrm{~g}$ $\mathrm{cm}^{-3}$ for eggs of the Black Sea $A$. tonsa laid at 16.5 to $17.2 \mathrm{psu}$. 


\section{Sinking of Calanus euxinus eggs in the salinity gradient of the Marmara Sea}

Calanus euxinus lay the majority of eggs during the nighttime (Sazhina 1987). In the Black Sea at night, $C$. euxinus females are usually located in the upper layers while, in daytime, they occur in the deep strata. However, in the Marmara Sea we found high numbers of $C$. euxinus females in brackish subsurface layers during daytime. The individuals of the Black Sea $C$. euxinus transferred into the Marmara Sea to avoid high-saline layers and aggregate in the upper layers (Svetlichny et al. 2010). Therefore, the eggs laid by females from the Black Sea in brackish (18 to 20 psu) subsurface layers of the Marmara Sea should descend to salinity gradient strata or even to a deep, high-saline (38.5 psu) zone.

The depth of sinking for eggs laid in subsurface layers and near the salinity gradient was calculated taking into account typical summer and winter vertical distribution of viscosity and conditional density of water in the Bosphorus region of the Marmara Sea (Kocatas et al. 1993, Balkis 2003, Tarkan et al. 2005) (Fig. 6).

To simplify the calculation, we made the following assumptions: (1) Egg sinking speed calculated in accordance with Stokes law was expressed as $V=$ $g d^{2}\left(\rho-\rho_{\mathrm{w}}\right) / 24 \eta$ (Stepanov \& Svetlichny 1981), where is the acceleration due to the gravity, $981 \mathrm{~cm} \mathrm{~s}^{2}, d$ is the diameter of eggs $(\mathrm{cm}), \rho$ is the mass density of eggs $\left(\mathrm{g} \mathrm{cm}^{-3}\right), \rho_{\mathrm{w}}$ is the density of the seawater $\left(\mathrm{g} \mathrm{cm}^{-3}\right), \eta$ is the dynamic molecular viscosity of the seawater (dyne $\mathrm{s} \mathrm{cm}^{-2}$ ). (2) The depth reached while sinking was evaluated as a sum of distances covered by eggs with mean mass density of $1.038 \mathrm{~g} \mathrm{~cm}^{-3}$ during $1 \mathrm{~h}$. (3) Egg development time $(D)$ was determined as $D=1014(T+$

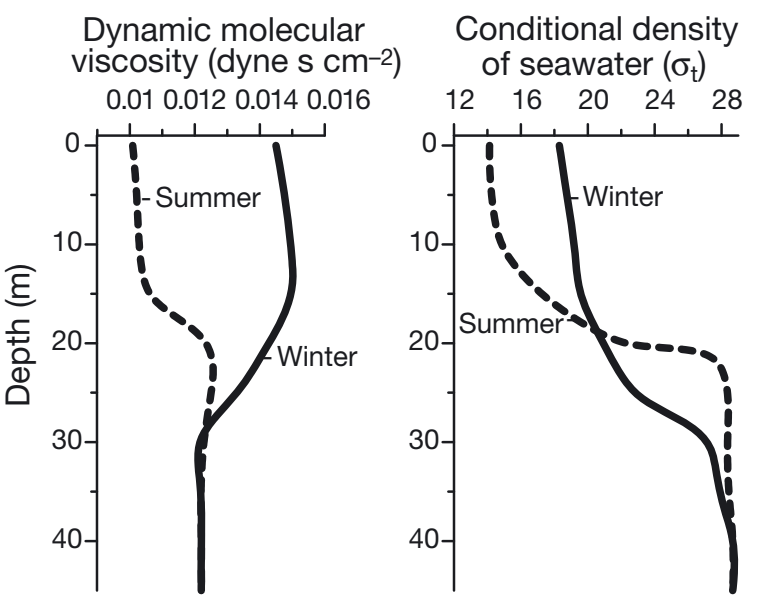

Fig. 6. Summer and winter profiles of dynamic molecular viscosity and conditional density of seawater calculated on the base of typical vertical distribution of temperature and salinity in the north-eastern part of the Marmara Sea
$10.94)^{-2.05}$ (Corkett et al. 1986), where $T$ is the mean temperature in the water column during egg sinking.

According to our estimation (Fig. 7), the eggs laid in low-saline layers of the Marmara Sea would descend to high-saline strata of the Mediterranean water in every season. In winter, the eggs can sink down to the depth of 34 to $35 \mathrm{~m}$ for 32 to $48 \mathrm{~h}$. Calanus euxinus eggs go through the layer of 23 to $31 \mathrm{~m}$ with maximum salinity gradient ( 25 to $37 \mathrm{psu}$ ) during $\sim 10 \mathrm{~h}$. Mean salinity changing rate in this layer is 1.2 psu per every hour of sinking. In summer, the depth of egg descending may be lower ( 28 to $30 \mathrm{~m}$ ) due to shorter development time (29 to 32 h). However, in this case, C. euxinus eggs should undergo more pronounced salinity increase than in winter. The eggs go through the layer of 15 to $22 \mathrm{~m}$ with the salinity gradient of 24 to $37 \mathrm{psu}$ during $8 \mathrm{~h}$ (mean salinity rate of $1.6 \mathrm{psu} \mathrm{h}^{-1}$ ) and experience severe salinity changes from 30 to $37 \mathrm{psu}$ for $3 \mathrm{~h}$ in 20 to $22 \mathrm{~m}$ strata (mean salinity rate of $2.3 \mathrm{psu} \mathrm{h}^{-1}$ ). Consequently, according to our estimation, the eggs of C. euxinus laid in the upper layers of the Marmara Sea should undergo salinity increases at a rate of $\sim 1.2$ to $2.3 \mathrm{psu} \mathrm{h}^{-1}$ during their sinking.

In laboratory experiments, all eggs of the Black Sea females died after gradual salinity increase from 18 to 39 psu at a rate of $1.5 \mathrm{psu} \mathrm{h}^{-1}$, in contrast to the eggs from the Marmara Sea females collected in deep high-saline layers (Fig. 3A). The hatching success of these eggs was $35 \%$ even after salinity changed at a rate of $\sim 6 \mathrm{psu} \mathrm{h}^{-1}$. Probably, the death of eggs from non-acclimatized females from the Black Sea at high salinity may have been the result of osmotic effects during hatching process. According to Marshall \& Orr (1972) and Davis (1959), nauplii burst out from eggs after cracking the outer membrane due to a sharp increase of pressure inside the inner case. The pressure increase seems to be caused by active absorption of water through the inner membrane. This suggestion may be confirmed by the increase in respiration rate of eggs at the hatching time (Nielsen et al. 2007). In our experiments during gradual salinity increase from 17 to $39 \mathrm{psu}$, the eggs of Calanus euxinus from the Black and Marmara Seas lost water and shrank. When the nauplii were about to exit, the volume of eggs restored. On the contrary, the eggs of non-acclimatized to high salinity $C$. euxinus from the Black Sea could not reconstruct their form, or the nauplii developed inside these eggs were unable to rupture the outer membrane under high osmotic pressure. However, low salinity tolerance of eggs of the Black Sea females that were not acclimatized to high salinity does not contradict with the conclusion about the Black Sea origin of C. euxinus population in the Marmara Sea (Isinibilir et al. 2009) because after parental acclimation to high salinity during $5 \mathrm{~d}$, the tolerance range in $C$. euxinus eggs increased (Svetlichny et al. 2010). 


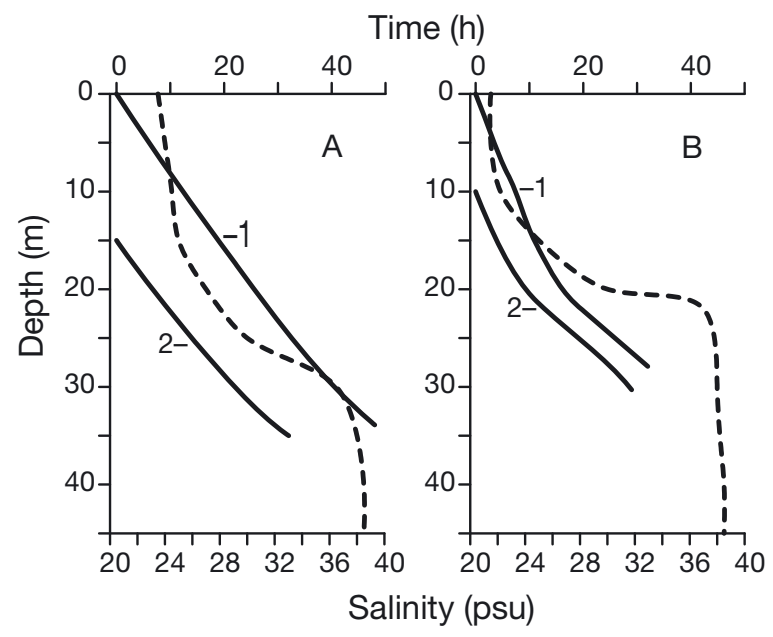

Fig. 7. Calanus euxinus. Sinking path of eggs until hatching laid by females near the sea surface (1) or near the salinity gradient (2) in the Marmara Sea in (A) winter and (B) summer. Dashed lines: salinity profiles

\section{Hatching success and sinking of eggs of Acartia clausi and A. tonsa in the Black and Marmara Seas}

Acartia clausi occur in the Black and Marmara Seas all year round. In our experiments, decrease in temperature from 20 to $7^{\circ} \mathrm{C}$ and increase in salinity from 22 to 39 psu did not affect hatching success of eggs of A. clausi from the high-saline Marmara Sea. However, a salinity increase from 18 to 39 psu resulted in significant decrease (up to $3-10 \%$ ) in egg hatching success of the low-saline Black Sea A. clausi. Probably, in eggs of the Marmara Sea A. clausi widening of salinity tolerance range may be due to high salinity parental acclimatization. On the contrary, the hatching success of subitaneous eggs of $A$. tonsa was high in the range of 18 to 39 psu being strongly affected by differences in temperature (Fig. 4), confirming the results of Hubareva et al. (2008) who observed a low tolerance to high salinity in A. clausi females from the Black Sea, in contrast to $A$. tonsa.

In the Marmara and Black Seas, the salinity and temperature gradient layers are located sufficiently near the surface (15 to $20 \mathrm{~m}$ ), therefore, for epiplanktonic Acartia, the probability that eggs sink to these strata is high.

We estimated possible depth of sinking of subitaneous eggs laid by Acartia clausi and A. tonsa in subsurface layers at $18 \mathrm{psu}$ and different temperatures in the range of 5 to $25^{\circ} \mathrm{C}$ based on mass density $(1.062$ and $1.047 \mathrm{~g} \mathrm{~cm}^{-3}$, respectively) obtained in our experiments and embryonic development time ( $D$, day). $D$ was calculated from the equations $D=1442(T+$ $10.49)^{-2.05}$ (McLaren 1978) for A. clausi and $D=489(T-$ 1.8) ${ }^{-2.05}$ (McLaren et al. 1969) for $A$. tonsa, with $T$ being temperature.
The sinking speed of subitaneous eggs in Acartia tonsa was 1.5 -fold higher than that in A. clausi at all temperatures (Fig. 8A). At 20 to $25^{\circ} \mathrm{C}$, embryonic development time amounted to $0.8-1.3 \mathrm{~d}$ in both species (Fig. 8B). However, at $10^{\circ} \mathrm{C}$, embryonic development time for $A$. tonsa was 2.2-fold higher than that for A. clausi. As a result, the sinking depth of eggs (until hatching of nauplii) in $A$. tonsa increased from $13 \mathrm{~m}$ at $25^{\circ} \mathrm{C}$ to $72 \mathrm{~m}$ at $10^{\circ} \mathrm{C}$, while that in $A$. clausi did not exceed $32 \mathrm{~m}$ even at $5^{\circ} \mathrm{C}$ (Fig. 8C).

In the Black Sea, Acartia tonsa develop at temperatures $>15^{\circ} \mathrm{C}$ (Gubanova 2000) in shallow (10 to $20 \mathrm{~m}$ ) bays where the water warms up from the surface to the bottom. At such temperatures, a large proportion of subitanious eggs spawned by $A$. tonsa could settle to the seabed before hatching. The potential influence of bioturbation, storms and current flow on the distribution of diapausing eggs on the sea bottom and their release from the sediments was discussed by Marcus (1984). However, little is known about hatching of subitanious eggs on the seabed. Probably, above-mentioned factors may result in translocation of subitanious eggs from the sediment surface to deeper strata. Moreover, the eggs of $A$. tonsa with spines can attach to the drifting material to stay in the water column.

In the deep regions of the Black Sea, the main part of Acartia tonsa eggs could descend to the cold intermediate layer $\left(6\right.$ to $\left.8^{\circ} \mathrm{C}\right)$. In our study, at such temperature, the hatching success of eggs was decreased to $50 \%$, and hatched nauplii were immobile or moved horizontally with the speed of 0.0035 to $0.01 \mathrm{~cm} \mathrm{~s}^{-1}$.

Titelman \& Kiørboe (2003) found that sinking speed in early naupliar stages of Acartia tonsa amounted to $0.013 \mathrm{~cm} \mathrm{~s}^{-1}$ at $18^{\circ} \mathrm{C}$. According to Svetlichny (1983), sinking speed of small copepods was proportional to dynamic viscosity of the seawater $\eta^{-n}$ with $n=1$. At $8^{\circ} \mathrm{C}, \eta$ is 1.3 -fold higher than that at $18^{\circ} \mathrm{C}$. Consequently, sinking speed of nauplii at $8^{\circ} \mathrm{C}$ should be $\sim 0.01 \mathrm{~cm} \mathrm{~s}^{-1}$, close to sinking speed of $A$. tonsa eggs from the Black Sea $\left(0.012 \mathrm{~cm} \mathrm{~s}^{-1}\right)$ at the same temperature. One may suggest that the moving speed of newly hatched nauplii $\left(0.01 \mathrm{~cm} \mathrm{~s}^{-1}\right)$ is too low to get out from the 'temperature trap' of deep layers in the Black Sea. On the contrary, at 20 to $25^{\circ} \mathrm{C}$ (temperature of the upper layers in warm season), newly hatched nauplii of $A$. tonsa may swim (Fig. 5) with the speed of $0.16 \mathrm{~cm}$ $\mathrm{s}^{-1}$. Titelman \& Kiørboe (2003) reported that at $18^{\circ} \mathrm{C}$ the swimming speed of early naupliar stages in $A$. tonsa was equal to $0.39 \mathrm{~cm} \mathrm{~s}^{-1}, 30$-fold higher than their sinking speed.

Probably, a high sinking speed of eggs and a low swimming activity of hatched nauplii in cold water $\left(\sim 8^{\circ} \mathrm{C}\right)$ are the reasons of low numbers of this species in the off-shore regions during the period of temperature stratification in the Black Sea. Our suggestion agrees 

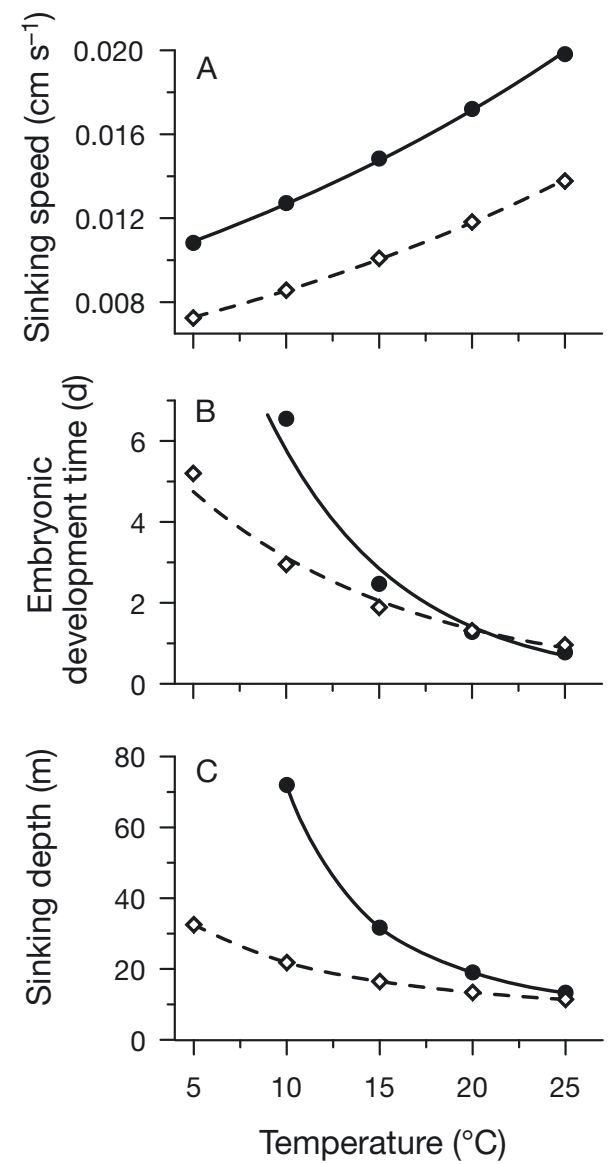

Fig. 8. Acartia clausi and A. tonsa. (A) Sinking speed, (B) embryonic development time and (C) sinking depth of eggs until hatching in A. tonsa (-) and A. clausi (---) at different temperatures

with the fact that nauplii of Acartia tonsa do not survive at $5^{\circ} \mathrm{C}$ (Chinnery \& Williams 2004) and even at $10^{\circ} \mathrm{C}$ (Tester \& Turner 1991).

In the Marmara Sea, descending Acartia tonsa eggs from warm ( 20 to $25^{\circ} \mathrm{C}$ ) and brackish (18 to $22 \mathrm{psu}$ ) to colder $\left(15^{\circ} \mathrm{C}\right)$ and high-saline (39 psu) layers may suppress the development of this species. In our experiments, minimum egg hatching success $(10.2 \pm 4.7 \%)$ in A. tonsa was recorded after simultaneous influence of low temperature and high salinity (Fig. 4). Tester \& Turner (1991) showed that at the salinity higher than 20 to 25 psu, survival of nauplii of $A$. tonsa decreased sharply. This may be the reason of the dramatic decrease in the abundance of that species in the Bosphorus area in the direction from the Black Sea to the Marmara Sea (Svetlichny et al. 2006). According Svetlichny et al. (2006), in October 2005, the number of A. tonsa decreased from 9800 individuals (ind.) $\mathrm{m}^{-2}$ in the northern Bosphorus to 5500 ind. $\mathrm{m}^{-2}$ in the southern Bosphorus and even to 275 ind. $\mathrm{m}^{-2}$ near the Prince Islands (north-western Marmara Sea). However, we found only isolated individuals of $A$. tonsa in summerautumn 2006-2008 in the Bosphorus area (unpubl. data).

\section{Vulnerability of Acartia clausi eggs in the upper layers of the Marmara Sea}

In Acarta clausi, embryonic development of eggs occurs in the upper homogeneous layers of the Black and Marmara Seas due to low sinking speed of eggs of this species. However, in subsurface layers, the mortality for Copepoda eggs may derive from epipelagic predators. On 27 June 2007 in the Bosphorus region of the Marmara Sea, we observed a great number of NoCtiluca scintillans (133750 to 177500 ind. $\mathrm{m}^{-2}$ ) with the eggs of $A$. clausi inside their body. The mean number of eggs in N. scintillans amounted to $5.1 \pm 2.5(\mathrm{n}=67)$. Consequently, the population of $N$. scintillans eliminated 682000 to 880000 eggs $\mathrm{m}^{-2}$ of A. clausi. If we assume a digestion time of 30 to $80 \mathrm{~h}$ (Daan 1987), digestion rate will be equal to 204805 to 704000 eggs $\mathrm{d}^{-1} \mathrm{~m}^{-2}$. Taking into account that in A. clausi egg production was estimated as $\sim 20$ eggs female ${ }^{-1} \mathrm{~d}^{-1}$ (Sazhina 1987), we calculated that $N$. scintillans eliminated the egg production of 10240 to 35200 females $\mathrm{m}^{-2}$. According to our data, in June 2007 in the Bosphorus Strait, the number of $A$. clausi females amounted to 5700 to 30250 ind. $\mathrm{m}^{-2}$. This indicates strong control of the population of A. clausi by N. scintillans. That estimation confirms the results from Quevedo et al. (1999) who determined that $N$. scintillans ingested $73 \%$ of the total stock of $A$. clausi eggs in neritic waters off the central Cantabrian coast.

Acknowledgements. The present study was partly supported by Turkish Scientific Technical Research Council-National Academy of the Ukraine (TUBITAK-NASU) joint projects 104Y208 and 107Y001 and a NATO Linkage Grant (EST NUKR CLG 983036).

\section{LITERATURE CITED}

Balkis N (2003) The effect of Marmara (Izmit) earthquake on the chemical oceanography of Izmit Bay, Turkey. Mar Pollut Bull 46:865-878

Belmonte G (1998) The egg morphology of 7 Acartiidae species: a preliminary survey of the ootaxonomy of calanoids. J Mar Syst 145:733-738

Bonnet B, Titelman J, Harris R (2004) Calanus the cannibal. J Plankton Res 26:937-948

- Brylinski JM (1981) Report of the presence of Acartia tonsa Dana (Copepoda) in the harbour of Dunkirk (France) and its geographical distribution in Europe. J Plankton Res 3: $255-260$

Castro-Longoria E (2003) Egg production and hatching success of four Acartia species under different temperature and salinity regimes. J Crustac Biol 23:289-299 
Ceballos S, Cabal JA, Alvarez-Marques F (2004) Reproductive strategy of Calanoides carinatus, and Calanus helgolandicus during a summer upwelling event off NW Spain. Mar Biol 145:739-750

Cervetto G, Gaudy R, Pagano M (1999) Influence of salinity on the distribution of Acartia tonsa (Copepoda, Calanoida). J Exp Mar Biol Ecol 239:33-45

Chinnery FE, Williams JA (2004) The influence of temperature and salinity on Acartia (Copepoda: Calanoida) nauplii survival. Mar Biol 145:733-738

Conover RJ (1956) Oceanography of Long Island Sound, 1952-1954. VI. Biology of Acartia clausi and A. tonsa. Bull Bingham Oceanogr Collect 15:156-233

Corkett CJ, McLaren IA, Sevigny JM (1986) The rearing of the marine calanoid copepods Calanus finmarchicus (Gunneris), C. glacialis Jaschnov and C. hyperboreus Kroyer with comment on the equiproportional rule. Syllogeus 58:539-546

Daan R (1987) Impact of egg predation by Noctiluca miliaris on the summer development of copepod populations in the southern North Sea. Mar Ecol Prog Ser 37:9-17

Daan R, Santiago R, Gonzalez SR, Klein Breteler WCM (1988) Cannibalism in omnivorous calanoid copepods. Mar Ecol Prog Ser 47:45-54

Davis CC (1959) Osmotic hatching in the eggs of some freshwater copepods. Biol Bull 116:15-29

Drillet G, Goetze E, Jepsen PM, Højgaard JK, Hansen BW (2008) Strain-specific vital rates in four Acartia tonsa cultures, I: strain origin, genetic differentiation and egg survivorship. Aquaculture 280(1-4):109-116

Farabegoli A, Ferrari I, Manzoni C, Pugnetti A (1989) Prima segnalazione nel Mare Adriatico del copepode calanoide Acartia tonsa Dana. Nova Thalassia 10:207-208

Fleminger A, Hulsemann K (1987) Geographical variation in Calanus helgolandicus s.l. (Copepoda, Calanoida) and evidence of recent speciation of the Black Sea population. Biol Oceanogr 5:43-81

Gross F, Raymont JEG (1942) The specific gravity of Calanus finmarchicus. Proc R Soc Edinb 61B:288-296

Gubanova A (2000) Occurrence of Acartia tonsa Dana in the Black Sea. Was it introduced from the Mediterranean? Medit Mar Sci 1:105-109

Guisande C, Harris R (1995) Effect of total organic content of eggs on hatching success and naupliar survival in the copepod Calanus helgolandicus. Limnol Oceanogr 40: 476-482

Hansen BW, Drillet G, Kozmer A, Madsen KV, Pedersen MF, Sørensen TF (2010) Temperature effects on copepod egg hatching: Does acclimatization matter? J Plankton Res 32: 305-315

Happel J, Brenner H (1965) Low Reynolds number hydrodynamics with special applications to particulate media. Prentice-Hall, Englewood Cliffs, NJ

- Holste L, Peck M (2006) The effects of temperature and salinity on egg production and hatching success of Baltic Acartia tonsa (Copepoda: Calanoida): a laboratory investigation. Mar Biol 148:1061-1070

Hubareva ES, Svetlichny LS, Kideys AE, Isinibilir M (2008) Fate of the Black Sea Acartia clausi and Acartia tonsa (Copepoda) penetrating into the Marmara Sea through the Bosphorus. Estuar Coast Shelf Sci 76:131-140

Isinibilir M, Svetlichny LS, Hubareva ES, Ustun F, Yilmaz NI, Kideys AE, Bat L (2009) Population dynamics and morphological variability of Calanus euxinus in the Black and Marmara Seas. Ital J Zool 76:403-414

Knutsen T, Melle W, Calise L (2001) Determining the mass density of marine copepods and their eggs with a critical focus on some of the previously used methods. J Plankton Res 23:859-873

Kocatas A, Koray T, Kaya M, Kara OF (1993) Review of the fishery resources and their environment in the Sea of Marmara. Studies and reviews, General Fisheries Council for the Mediterranean (GFCM), FAO 64:87-143

Kovalev AV, Besiktepe S, Zagorodnyaya J, Kideys AE (1998) Mediterraneanization of the Black Sea zooplankton is continuing. In: Ivanov L, Oguz T (eds) Ecosystem modeling as a management tool for the Black Sea. NATO Science Series 2. Environmental Security Vol 47. Kluwer Academic Publishers, Dordrecht, p 199-207

> Landry MR (1978) Population dynamics and production of a planktonic marine copepod, Acartia clausi, in a small temperate lagoon on San Juan Island, Washington. Int Rev Gesamten Hydrobiol 63:77-119

Marcus NH (1984) Recruitment of copepod nauplii into the plankton: importance of diapause eggs and benthic processes. Mar Ecol Prog Ser 15:47-54

> Marcus NH, Fuller CM (1986) Subitaneous and diapause eggs of Labidocera aestiva Wheeler (Copepoda: Calanoida): differences in fall velocity and density. J Exp Mar Biol Ecol 99:247-256

Marshall SM, Orr AP (1972) The biology of a marine copepod. Springer-Verlag, New York, NY

Marshall SM, Orr AP, Rees CB (1953) Calanus finmarchicus and related forms. Nature 171:1163-1164

Mauchline J (1998) The biology of calanoid copepods. In: Blaxter JHS, Southward AJ, Tyler PA (eds) Advances in marine biology, Vol 33. Academic Press, San Diego, CA

McLaren IA (1978) Generation lengths of some temperate marine copepods: estimation, prediction, and implications. J Fish Res Board Can 35:1330-1342

McLaren IA, Corkett CJ, Zilliox EJ (1969) Temperature adaptation of copepod eggs from the Arctic to the tropics. Biol Bull137:486-493

Miller DD, Marcus NH (1994) The effects of salinity and temperature on the density and sinking velocity of eggs of the calanoid copepod Acartia tonsa Dana. J Exp Mar Biol Ecol 179:235-252

> Nagaraj M (1988) Combined effects of temperature and salinity on the complete development of Eurytemora velox (Crustacea: Calanoida). Mar Biol 99:353-358

> Nielsen P, Larsen LH, Ramløv H, Hansen BW (2007) Respiration rates of subitaneous eggs from a marine calanoid copepod: monitored by nanorespirometry. J Comp Physiol B 177:287-296

Ohman MD, Hirche HJ (2001) Density-dependent mortality in an oceanic copepod population. Nature 412:638-641

Ohs CL, Rhyne AL, Stenn E (2009) Viability of subitaneous eggs of the copepod, Acartia tonsa (Dana), following exposure to various cryoprotectants and hypersaline water. Aquaculture 287(1-2):114-119

Paffenhöfer GA, Stearns DE (1988) Why is Acartia tonsa (Copepoda: Calanoida) restricted to nearshore environments? Mar Ecol Prog Ser 42:33-38

Papadopoulos LN, Peijnenburg KTCA, Luttikhuizen PC (2005) Phylogeography of the calanoid copepods Calanus helgolandicus and $C$. euxinus suggests Pleistocene divergences between Atlantic, Mediterranean, and Black Sea populations. Mar Biol 147:1353-1365

Pedersen K (2005) Development rates of eggs from the calanoid copepod Acartia tonsa (DANA) at high and low temperatures. 3rd module environmental biology project, Roskilde University, available at diggy.ruc.dk/bitstream/ 1800/1448/1/projekt.pdf 
Poulet SA, Laabir M, Ianora A, Miralto A (1995) Reproductive response of Calanus helgolandicus. I. Abnormal embryonic and naupliar development. Mar Ecol Prog Ser 129:85-95

Quevedo M, Gonzalez-Quiros R, Anadon R (1999) Noctiluca evidence of heavy predation by Noctiluca scintillans on Acartia clausi (Copepoda) eggs off the central Cantabrian coast (NW Spain). Oceanol Acta 22:127-131

Roman MR, Gauzens AL, Rhinehart WK, White JR (1993) Effects of low oxygen waters on Chesapeake Bay zooplankton. Limnol Oceanogr 38:1603-1614

Salzen EA (1956) The density of the eggs of Calanus finmarchicus. J Mar Biol Assoc UK 35:549-554

Sazhina LI (1987) Reproduction, growth, productivity of marine Copepoda. Naukova Dumka, Kiev (in Russian)

Sei S, Ferrari I (2008) First report of the occurrence of Acartia tonsa (Copepoda: Calanoida) in the Lesina Lagoon (south Adriatic Sea-Mediterranean Sea). Mar Biodivers Rec 1:e37 doi:10.1017/S1755267206003915

Stepanov VN, Svetlichny LS (1981) The studies on hydromechanic characteristics of planktonic copepods. Naukova Dumka, Kiev (in Russian)

Svetlichny LS (1983) Hydrodynamic resistance of motionless copepods during their passive sinking in water. Okeanology 23(1):139-144

Svetlichny LS, Hubareva ES, Kideys AE, Isinibilir M, Shmeleva A (2006) Zooplankton community state in the Northeastern Marmara Sea during early autumn with comments on mass mortality of the Black Sea species due to the salinity gradient. J Black Sea / Medit Environ 12:213-231

Svetlichny LS, Hubareva ES, Isinibilir M, Kideys AE, Belmonte G (2010) Salinity tolerance of Calanus euxinus in the Black and Marmara Seas. Mar Ecol Prog Ser 404:127-138

Tang KW, Dam HG, Feinberg LR (1998) The relative importance of egg production rate, hatching success, hatching duration and egg sinking in population recruitment of two species of marine copepods. J Plankton Res 20:1971-1987

Tarkan AN, Inibilir M, Tarkan AS (2005) Seasonal variations of the zooplankton composition and abundance in the Istanbul Strait. Pak J Biol Sci 8:1327-1336

Editorial responsibility: Benni Hansen,

Roskilde, Denmark
Tester PA, Turner JT (1991) Why is Acartia tonsa restricted to estuarine habitats? Proc 4th Int Copepod Conference. Bull Plankton Soc Japan (Spec Vol): 603-611

> Titelman J, Kiørboe T (2003) Motility of copepod nauplii and implications for food encounter. Mar Ecol Prog Ser 247: 123-135

> Unal E, Frost BW, Armbrust V, Kideys AE (2006) Phylogeography of Calanus helgolandicus and the Black Sea copepod Calanus euxinus, with notes on Pseudocalanus elongatus (Copepoda, Calanoida). Deep-Sea Res II 53: 1961-1975

Uye S (1980a) Development of neritic copepods Acartia clausi and A. steueri. I. Some environmental factors affecting egg development and the nature of resting eggs. Bull Plankton Soc Japan 27:1-9

Uye S (1980b) Development of neritic copepods Acartia clausi and A. steueri. II. Isochronal larval development at various temperatures. Bull Plankton Soc Japan 27: $11-18$

Uye S, Fleminger A (1976) Effect of various environmental factors on egg development of several species of Acartia in southern California. Mar Biol 38:253-262

> Uysal Z, Kideys AE, Shmeleva AA, Zagorodnyaya JA, Gubanova AD (2002) Checklist of copepods (Calanoida and Podoplea) from the northern Levantine basin shelf waters. Hydrobiologia 482:15-21

Villante F, Ruiz A, Franco J (1993) Summer zonation and development of zooplankton populations within a shallow mesotidal system: the estuary of Mundaka. Cah Biol Mar 34:131-143

Vinogradov ME, Sapozhnikov VV, Shushkina EA (1992) The Black Sea ecosystem. Nauka, Moskow (in Russian)

Williams R, Convay DVP, Collins NR (1987) Vertical distributions of eggs, nauplii and copepodites of Calanus helgolandicus (Copepoda: Crustacea) in the Celtic Sea. Mar Biol 96:247-252

Zagami G, Guglielmo L (1990) Prima segnalazione nel Mar Tirreno del copepode pelagico Acartia tonsa Dana. Mem Biol Mar Oceanogr 18:71-74

Submitted: March 23, 2010; Accepted: September 22, 2010 Proofs received from author(s): November 11, 2010 